\title{
EVALUASI DAYA TAHAN IKAN MAS HASIL SELEKSI BERDASARKAN MARKA MOLEKULER MHC-II TERHADAP INFEKSI KOI HERPES VIRUS
}

\author{
Erma Primanita Hayuningtyas"\#, Khairul Syahputra"', dan Didik Ariyanto") \\ ") Balai Penelitian dan Pengembangan Budidaya Ikan Hias \\ ") Balai Penelitian Pemuliaan Ikan
}

(Diterima publikasi: 2 April 2014; Revisi final: 29 Januari 2015; Disetujui publikasi: 11 Maret 2015)

\begin{abstract}
ABSTRAK
Balai Penelitian Pemuliaan Ikan telah menghasilkan populasi ikan mas tahan Koi Herpes Virus (KHV) generasi pertama (F-1) melalui program selective breeding. Seleksi dilakukan dengan metode walk-back selection menggunakan marka gen MHC-II spesifik pada lokus Cyca-Cyca-DAB 1*05. Penelitian ini bertujuan untuk mengevaluasi daya tahan benih ikan mas F-1 terseleksi terhadap infeksi KHV melalui uji tantang. Sebagai pembanding, digunakan ikan mas populasi benih F-1 non-seleksi dan populasi benih ikan mas dari unit pembenihan rakyat (UPR). Ikan uji berupa benih ikan mas Rajadanu berumur dua bulan dengan bobot ratarata 5,5 $\pm 0,5 \mathrm{~g}$. Jumlah benih pada masing-masing wadah perlakuan sebanyak 30 ekor dengan tiga kali pengulangan. Wadah pengujian berupa akuarium berukuran $40 \mathrm{~cm}$ x $60 \mathrm{~cm}$ x $40 \mathrm{~cm}$ dengan kepadatan 1 ekor/L. Parameter yang diamati adalah sintasan, deteksi KHV, analisis ekspresi gen MHC-II, dan gambaran darah ikan. Hasil penelitian menunjukkan bahwa populasi benih F-1 terseleksi memiliki daya tahan lebih baik dengan sintasan 93,33\% dibandingkan populasi benih F-1 non-seleksi sebesar 85,55\% dan populasi benih dari UPR sebesar $81,11 \%$. Daya tahan yang tinggi pada populasi benih F-1 terseleksi didukung oleh hasil deteksi KHV yang negatif dan persentase jumlah limfosit yang lebih tinggi sebesar 91,67\%; serta rendahnya persentase monosit dan heterofil, selain itu, tidak adanya eosinofil dan basofil. Ekspresi gen MHC-II terdeteksi pada berbagai organ, ekspresi tertinggi ditemukan pada organ limpa.
\end{abstract}

KATA KUNCI: ikan mas (Cyprinus carpio), daya tahan, MHC-II, Koi Herpes Virus (KHV)

ABSTRACT: Evaluation the resistant of common carp selection product with help MHC-II marker regarding of Koi Herpes Virus (KHV) infection. By: Erma Primanita Hayuningtyas, Khairul Syahputra, and Didik Ariyanto

Research Institute for Fish Breeding (RIFB) has produced first generation (G-1) of common carp population of Koi herpes virus resistant through selective breeding program. Selection program was done with the walk-back selection using gene marker of MHC-II specific to Cyca-DAB 1*05 locus. The purpose of this experiment was to evaluate the resistant of carp broodstock F-1 selected population against KHV infection by co-habitation challenge test for 21 days. As comparison unselected corp broodstock were used to compare selected one sand broodstock carp population from Fish Breeding Unit. Each treatment use 30 fishs with size of $5.5 \pm 0.5 \mathrm{~g}$ of two months old fish. The experiment was corned out with three replicates. The fish was reared at aquarium with size of $40 \mathrm{~cm} \times 60 \mathrm{~cm} \times 40 \mathrm{~cm}$ with density $1 \mathrm{pcs} / \mathrm{L}$. The parameters of observed was survival rate, KHV detection, MHC-II gene expression analize, and hematology of fish in the end of experiment, and water quality was used as data support. Result of research showed that broodstock carp F-1 selected population have better body resistant with survival rate of 93.33\% higher than F-1 non selected population with survival rate of $85.55 \%$, and compared with broodstock population from Fish Breeding Unit with survival rate of $81.11 \%$. The high of body resistant from broodstock F-1 selected population was supported by the negative detection of KHV, the high of limfosit percentage (91.67\%), the low of monosit and heterofil percentage, and absence of eosinofil and basofil in broodstock selected population. Resulted on MHC-II gene expression analysis showed that the highest MHC-II expression existed on spleen organ.

KEYWORDS: carp (Cyprinus carpio), resistant, MHC-II, Koi Herpes Virus (KHV)

\# Korespondensi: Balai Penelitian dan Pengembangan Budidaya Ikan Hias. Jl. Perikanan No. 13, Pancoran Mas, Depok 14634. Indonesia. Tel.: + (021) 7520482

E-mail: erma_primanita@yahoo.com 


\section{PENDAHULUAN}

Budidaya ikan mas (Cyprinus carpio) di Indonesia telah dimulai sejak akhir abad ke-19. Sejak saat itu, budidaya ikan mas mengalami perkembangan yang cukup pesat. Namun perkembangan budidaya ikan mas di Indonesia mengalami kendala yang sangat serius dengan munculnya wabah penyakit KHV (Koi Herpes Virus) yang terjadi sejak tahun 2002 (Sunarto, 2005). Wabah ini telah menyebabkan penurunan produksi budidaya ikan mas di Indonesia secara signifikan. Beberapa upaya yang telah dilakukan untuk menanggulangi wabah penyakit ini umumnya melalui peningkatan daya tahan tubuh ikan mas secara eksternal, antara lain pemberian vaksin dan imunostimulan dari berbagai jenis tumbuhan, serta material lainnya seperti chromium yeast (Mudjiutami et al., 2007; Santika et al., 2008; Zainun, 2007). Namun demikian, upaya yang dilakukan belum memberikan hasil yang optimal. Salah satu upaya yang belum banyak dilakukan adalah meningkatkan daya tahan ikan mas secara internal agar mampu menghadapi serangan penyakit KHV. Peningkatan daya tahan secara internal tersebut dapat dilakukan melalui program perbaikan genetik/ pemuliaan. Keberhasilan program pemuliaan ini diharapkan menjadi solusi untuk menghasilkan strain ikan mas yang mempunyai daya tahan tinggi terhadap serangan KHV.

Banyaknya strain ikan mas yang berkembang di masyarakat menunjukkan tingginya tingkat keragaman genetik ikan mas. Hal ini merupakan modal penting dalam kegiatan pemuliaan. Program pemuliaan ikan mas tahan KHV di Balai Penelitian Pemulian Ikan, Sukamandi dimulai tahun 2010 dengan mengoleksi plasma nutfah ikan mas di antaranya ikan mas strain Majalaya (Bandung), Rajadanu dan Sutisna (Kuningan), Wildan (Cianjur), dan Sinyonya (Pandeglang). Hasil evaluasi ketahanan masing-masing strain ikan mas terhadap infeksi KHV menunjukkan bahwa strain Rajadanu memiliki ketahanan lebih baik dibanding empat strain lainnya (Ariyanto et al., 2010a; Ariyanto et al., 2010b). Selanjutnya dibentuk populasi dasar (F0) ikan mas strain Rajadanu tahan KHV dengan melakukan seleksi individu berdasarkan marka molekuler Major Histocompatibility Complex class II (MHC-II). Gen MHC-II dapat digunakan sebagai penanda untuk ikan mas tahan KHV karena fungsinya memproduksi antibodi dan mengaktivasi karakter-karakter imunologi yang terlibat dalam mengeliminasi parasit, bakteri, dan menetralkan virus (Sucipto et al., 2011). Individuindividu terseleksi berdasarkan marka molekuler tersebut selanjutnya dijadikan sebagai induk dalam rangka pembentukan generasi berikutnya (F-1).

Tujuan dari penelitian ini adalah untuk mengetahui daya tahan benih ikan mas F-1 hasil seleksi ber- dasarkan marka molekuler MHC-II, terhadap infeksi penyakit Koi Herpes Virus (KHV). Evaluasi ini dilakukan untuk mengetahui efektivitas seleksi yang dilakukan pada generasi sebelumnya (F-0).

\section{BAHAN DAN METODE}

Penelitian ini dilaksanakan di Laboratorium Balai Penelitian Pemuliaan Ikan, Sukamandi pada bulan Maret 2012 sampai Oktober 2012. Ikan mas strain Rajadanu yang digunakan dalam penelitian ini adalah benih F-1, yang merupakan turunan dari induk betina dan jantan terseleksi MHC-II. Sebagai kontrol internal digunakan benih ikan mas F-1 dari induk betina dan jantan negatif MHC-II. Sebagai kontrol eksternal, digunakan benih ikan mas yang berasal dari Unit Pembenihan Rakyat (UPR). Benih uji berumur sekitar dua bulan dengan bobot rata-rata benih 5,5 $\pm 0,5 \mathrm{~g} /$ ekor. Masing-masing perlakuan diuji dengan tiga kali ulangan.

\section{Uji Tantang}

Pengamatan daya tahan benih ikan mas terhadap infeksi KHV dilakukan melalui uji tantang secara laboratoris. Uji tantang dilakukan dengan metode kohabitasi, mengikuti prosedur dalam protokol pemuliaan ikan mas (Gambar 1) (Anonim, 2010). Wadah pengujian berupa akuarium berukuran $60 \mathrm{~cm}$ x $40 \mathrm{~cm}$ x $40 \mathrm{~cm}$ yang diisi air sebanyak 30 liter. Pada masingmasing akuarium dimasukkan 30 ekor ikan uji ditambah ikan terinfeksi KHV sebanyak tiga ekor.

Pada percobaan ini, ikan uji yang digunakan harus memiliki status kesehatan bebas dari KHV yang diverifikasi dengan uji PCR, serta bebas dari parasit dan bakteri. Jika benih uji terindikasi positif KHV, maka tidak dapat digunakan dalam pengujian, sedangkan jika terinfeksi bakteri atau parasit, harus dihilangkan terlebih dahulu. Langkah lain yang harus dipersiapkan adalah menyediakan ikan sumber KHV. Ikan sumber dibuat dengan cara menyuntikkan filtrate homogenate $\mathrm{KHV}$ dengan dosis $0,1 \mathrm{~mL} /$ ekor. Filtrate homogenate $K H V$ diperoleh dari insang ikan yang terinfeksi KHV yang dihancurkan, kemudian di-sentrifuge selama 15 menit pada kecepatan $5.000 \mathrm{rpm}$ lalu disaring menggunakan syrige filter $0,45 \mathrm{~mm}$. Setelah disuntik filtrate homogenate $K H V$, calon ikan sumber KHV dipelihara pada akuarium yang bersuhu rendah berkisar $21^{\circ} \mathrm{C}-23^{\circ} \mathrm{C}$. Ikan yang memiliki gejala klinis terinfeksi KHV dikoleksi dan diberi penandaan berupa pemotongan sirip ekor dan dideteksi dengan PCR, selanjutnya dapat digunakan sebagai ikan sumber KHV.

Sebelum uji tantang dilakukan, ikan uji diaklimatisasi terlebih dahulu pada suhu rendah sekitar $\pm 22^{\circ} \mathrm{C}$ selama 1-2 hari. Suhu air pada akuarium uji tantang 


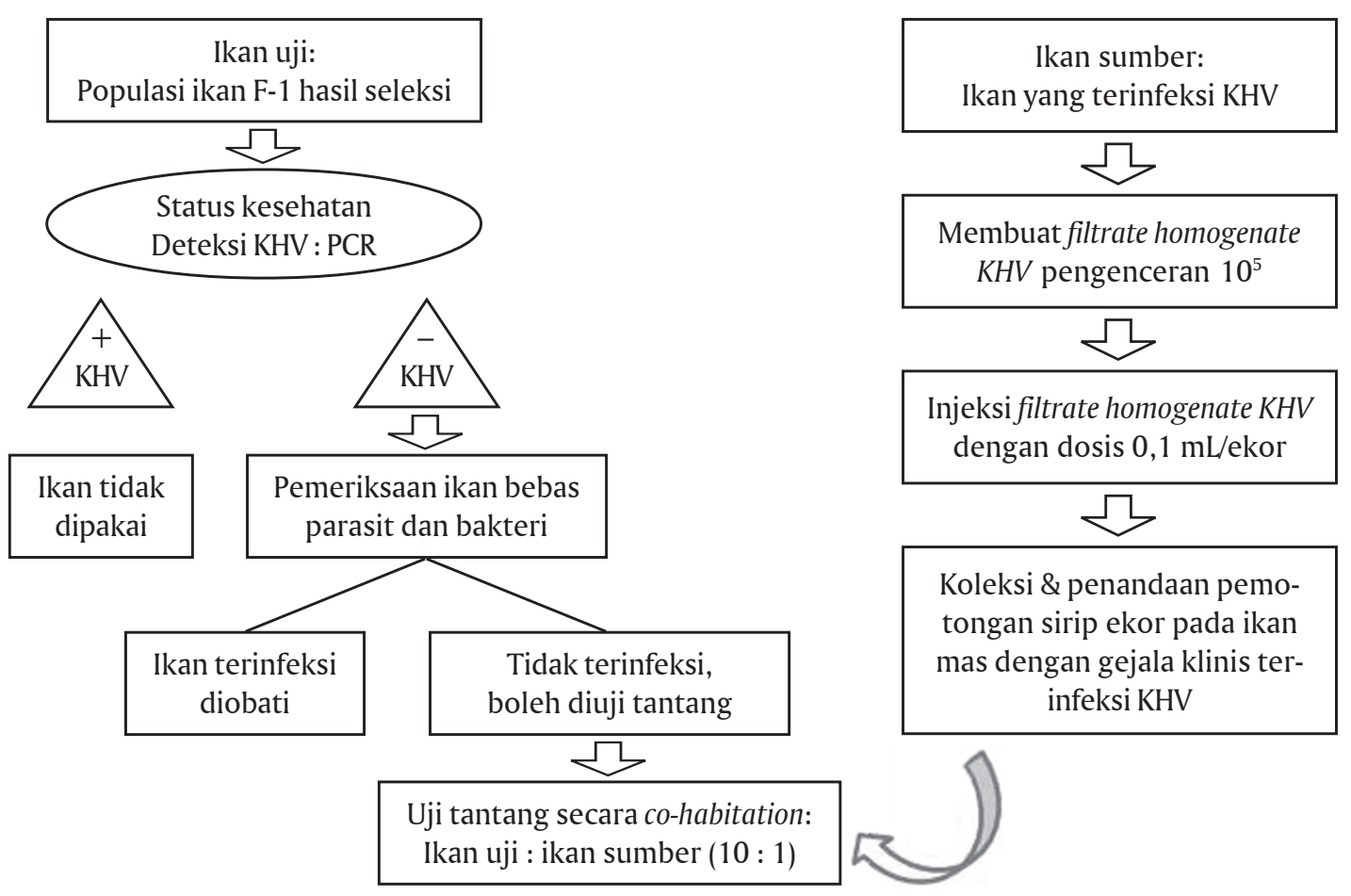

Gambar 1. Skema prosedur uji tantang KHV, persiapan ikan uji, dan ikan terinfeksi KHV (Protokol Pemuliaan Ikan Mas, 2010)

Figure 1. Schematic procedure of KHV challenge test, preparation for tested fish, and KHV-infected fish (Carp Selective Breeding Protocol, 2010)

juga dikondisikan pada suhu yang permisif bagi berkembangnya virus $\mathrm{KHV}$ berkisar $21^{\circ} \mathrm{C}-23^{\circ} \mathrm{C}$. Uji tantang dilakukan selama 21 hari pemeliharaan. Setiap harinya, ikan diberi pakan sebanyak 3\% bobot biomassa/hari, agar ikan dapat bertahan hidup. Penyiponan dan pergantian air dilakukan untuk membuang sisa pakan, agar air tidak berdampak toksik bagi ikan.

\section{Parameter Pengamatan}

Dalam penelitian ini dilakukan pengamatan deteksi KHV dengan metode PCR, sintasan, analisis ekspresi marka MHC-II, serta gambaran darah ikan uji. Deteksi KHV dilakukan pada awal, saat terjadi kematian dan akhir penelitian. Performansi daya tahan benih ikan mas terhadap KHV diamati melalui tiga pendekatan, yaitu:

\section{Deteksi KHV dengan Metode PCR}

Deteksi KHV dilakukan pada ikan sebelum diuji tantang, pada saat ikan menunjukkan gejala klinis terserang KHV dan pada ikan di akhir percobaan. Organ yang diambil sebagai sampel adalah insang. Isolasi DNA dilakukan sesuai SNI 7547:2009. Sedangkan amplifikasi PCR dilakukan menggunakan kit Maxima Hot Start Green PCR master Mix 2X (Thermo science) diamplifikasi dengan menggunakan primer SPHL-5. PCR dilakukan dengan komposisi pereaksi yang dimodifikasi dari SNI 7547:2009: $1 \mu \mathrm{L}$ primer forward
(5'GACACCACATCTGCAAGGAG-3), $1 \mu \mathrm{L}$ primer reverse (5'GACACATGTTACAATGGTCGC-3) masing-masing dengan konsentrasi $20 \mu \mathrm{M}, 1 \mu \mathrm{L}$ DNA, dan nuclease free water sampai total volume $25 \mu \mathrm{L}$. Kondisi amplifikasi PCR dilakukan dengan program sesuai SNI 7547:2009 (revisi): denaturasi awal $95^{\circ} \mathrm{C}$ selama lima menit; suhu denaturasi $94^{\circ} \mathrm{C}$ selama 30 detik, suhu annealing $55^{\circ} \mathrm{C}$ selama 30 detik, dan ekstensi $72^{\circ} \mathrm{C}$ selama 30 detik, siklus ini diulang sebanyak 40 kali; diakhiri dengan ekstensi akhir $72^{\circ} \mathrm{C}$ selama tujuh menit dan kondisi akhir $4^{\circ} \mathrm{C}$. Selanjutnya hasil PCR dapat langsung dielektroforesis pada gel agarose dengan konsentrasi 1,5\% bersama marker $100 \mathrm{bp}$ DNA leader (Vivantis). Panjang fragment yang dihasilkan adalah $290 \mathrm{bp}$.

\section{Deteksi Gen dan Analisis Ekspresi Gen dengan Marka MHC-II}

Tingkat ekspresi gen dari marka MHC-II dapat diketahui melalui deteksi gen MHC-II dan analisis ekspresi gen MHC-II pasca dilakukannya uji tantang. Analisis ekspresi gen dilakukan pada benih ikan mas F-1 terseleksi yang masih hidup setelah uji tantang. Tahapan awal sebelum analisis ekspresi gen MHC-II dilakukan deteksi gen MHC-II terlebih dahulu terhadap ikan uji yaitu ikan F-1 terseleksi, F-1 non-seleksi, dan benih ikan mas dari UPR. Deteksi gen MHC-II dilakukan berdasarkan prosedur deteksi MHC-II pada Pro- 
tokol Pemuliaan Ikan Mas pada Direktorat Jenderal Perikanan Budidaya, dengan menggunakan lokus CycaDAB 1*05 (Rakus et al., 2008); yang sudah dimodifikasi suhu annealing-nya menjadi $49,1^{\circ} \mathrm{C}$ (Hayuningtyas et al., 2013).

\section{Pengambilan dan Preparasi Sampel}

Sampel yang digunakan untuk deteksi gen MHC II adalah organ sirip ekor untuk diekstraksi DNA. Jumlah sampel yang digunakan sebanyak tiga ekor atau $10 \%$ dari total tebar ikan. Sebagai kontrol positif menggunakan ikan positif MHC-II yang tidak diuji tantang. Setelah ikan diambil siripnya selanjutnya dilakukan pengambilan sampel untuk analisis ekspresi gen MHCII. Ikan uji dibius terlebih dahulu dengan eugenol, selanjutnya dibedah untuk memperoleh organ limpa, ginjal, usus, dan thymus. Organ yang sudah diperoleh kemudian masing-masing ditimbang dengan kisaran 0,1-0,3 mg; lalu dimasukkan ke dalam $500 \mu$ L larutan Tri reagent Kit dan digerus dengan pestel sampai lisis (untuk analisis ekspresi MHC-II).

\section{Deteksi Gen MHC-II}

Deteksi gen MHC-II dilakukan dengan mengisolasi DNA dari organ sirip ekor dengan menggunakan prosedur Gene JET Genomic DNA Purification Kit. Setelah menghasilkan genom DNA selanjutnya diamplifikasi menggunakan mesin PCR. Amplifikasi DNA deteksi MHC-II menggunakan primer Cyca-DAB 1*05 (Rakus et al., 2008), pada Thermocycler Gradient (Esco) dilakukan menggunakan kit Maxima Hot Start Green PCR master Mix $2 X$ (Thermo science). Komposisi reagent terdiri atas: $1 \mu \mathrm{L}$ primer forward ('5-CTAATGGATACTACTGG-3'), $1 \mu \mathrm{L}$ primer reverse ('5-ATCGCTGACTGTCTGTT-3') masing-masing primer dengan konsentrasi 20 pmol, $1 \mu \mathrm{L}$ DNA, dan nuclease free water sampai total volume $25 \mu \mathrm{L}$. Kondisi amplifikasi PCR dilakukan dengan program: denaturasi awal $95^{\circ} \mathrm{C}$ selama tiga menit; Suhu denaturasi $95^{\circ} \mathrm{C}$ selama 30 detik, suhu annealing $49,1^{\circ} \mathrm{C}$ selama 30 detik, dan ekstensi $72^{\circ} \mathrm{C}$ selama satu menit, siklus ini diulang sebanyak 30 kali; diakhiri dengan ekstensi akhir $72^{\circ} \mathrm{C}$ selama tujuh menit dan kondisi akhir $4^{\circ} \mathrm{C}$. Selanjutnya hasil PCR dapat langsung dielektroforesis pada gel agarose dengan konsentrasi 1,5\% bersama marker 100 bp DNA leader (Vivantis). Fragment DNA yang dihasilkan dari amplifikasi PCR adalah 300 bp.

\section{Analisis Ekspresi Gen MHC-II}

Ikan yang terdeteksi membawa gen MHC-II, selanjutnya dianalisis dengan dicek ekspresi gen MHCII pada organ limpa, ginjal, usus, dan thymus (Rodrigues et al., 1995). Masing-masing organ diisolasi total RNA-nya menggunakan prosedur Tri Reagent
Kit. Selanjutnya disintesis cDNA menggunakan Ready To Go You Prime First Strand Beads (GE Healthcare). Pengamatan ekspresi dilakukan dengan mengukur ekspresi gen MHC-II menggunakan PCR semi kuantitatif. cDNA yang dihasilkan diamplifikasi menggunakan primer Cyca DAB 1*05 dengan komposisi dan program yang sama dengan deteksi MHC-II namun pengulangan siklus dikurangi menjadi 25 kali.

Sebagai kontrol internal digunakan $\beta$-aktin ikan mas dengan komposisi reagent terdiri atas: $1 \mu \mathrm{L}$ primer forward (5'-CCC TGG CCC CCA GCA CAA TG-3'), $1 \mu \mathrm{L}$ primer reverse (5'-TCT GCG CAG TTG AGT CGG CG-3') masing-masing primer dengan konsentrasi 20 pmol, $1 \mu \mathrm{L}$ DNA, dan nuclease free water sampai total volume $25 \mu \mathrm{L}$. Kondisi amplifikasi PCR dengan program: suhu denaturasi awal $95^{\circ} \mathrm{C}$ selama lima menit; suhu denaturasi $94^{\circ} \mathrm{C}$ selama 30 detik, suhu annealing $70^{\circ} \mathrm{C}$ selama 30 detik, dan ekstensi $72^{\circ} \mathrm{C}$ selama satu menit; siklus ini diulang sebanyak $30 \mathrm{kali}$; diakhiri dengan ekstensi akhir $72^{\circ} \mathrm{C}$ selama 10 menit dan pengkondisian akhir pada suhu $4^{\circ} \mathrm{C}$. Selanjutnya hasil PCR dapat langsung dielektroforesis atau disimpan dalam lemari pendingin. Fragment DNA yang dihasilkan dari amplifikasi PCR adalah $240 \mathrm{bp}$.

Analisis ekspresi gen MHC-II dilakukan dengan membandingkan rasio ekspresi gen MHC-II : gen $\beta$ aktin ikan mas, antara perlakuan yang membawa gen MHC-II dengan kontrol (positif MHC-II). Analisis ekspresi gen MHC-II dilakukan menggunakan software Gen Analyzer 2010.

\section{Gambaran Darah Ikan}

Pengamatan gambaran darah dilakukan pada awal dan akhir uji tantang, dengan parameter pengamatan adalah diferensiasi leukosit. Diferensiasi leukosit yang diamati di antaranya adalah limfosit, monosit, heterofil, eosinofil, dan basofil. Preparasi pengamatan gambaran darah diawali dengan penggambilan darah pada bagian kepala ikan menggunakan syringe yang sudah dibasahi dengan antikoagulan heparin. Darah diteteskan pada ujung objek glass kemudian didorong sepanjang permukaan kaca menggunakan objek glass lainnya sehingga membentuk lapisan tipis dan merata. Preparat kemudian diwarnai dengan cara dimasukkan ke dalam larutan pewarnaan Giemsa 10\% selama 30 menit, kemudian dicuci dengan air dan dikeringkan di udara. Terakhir, preparat diperiksa di bawah mikroskop dimulai dengan pembesaran rendah untuk orientasi dan memilih daerah ulasan yang baik untuk pengamatan. Pengamatan dan identifikasi sel-sel leukosit menggunakan pembesaran 1.000x dengan menggunakan minyak emersi. Penghitungan dilakukan hingga mencapai jumlah 100 buah sel leukosit, dan hasilnya dinyatakan dalam persen. 


\section{Pengamatan Kualitas Air Media Uji Tantang}

Sebagai data pendukung penelitian dilakukan pengamatan terhadap parameter kualitas perairan media uji tantang meliputi: suhu, pH, oksigen terlarut, nitrit, nitrat, TAN, konduktivitas, dan turbiditas. Pengamatan dilakukan setiap dua hari sekali.

\section{HASIL DAN BAHASAN}

Setelah melalui masa uji tantang selama 21 hari secara kohabitasi, ketiga populasi ikan mas menghasilkan sintasan yang berbeda-beda. Secara umum nilai sintasan yang dihasilkan tidak berbeda nyata $(P>0,05)$. Nilai sintasan yang tertinggi adalah pada populasi benih F-1 terseleksi sebesar 93,33\% \pm 6,67\%; selanjutnya populasi benih F-1 non-seleksi sebesar $85,55 \% \pm 25,02 \%$ dan terendah pada populasi benih dari UPR sebesar $81,11 \% \pm 21,17 \%$. Tingginya persentase sintasan pada populasi benih F-1 terseleksi disebabkan oleh tidak terdeteksinya KHV pada populasi benih terseleksi, sedangkan pada populasi F-1 non-seleksi dan benih UPR terdeteksi serangan KHV pada ikan uji (Gambar 2). Pada populasi benih F-1 non-seleksi terdapat satu ulangan dari tiga ulangan yang terdeteksi positif KHV. Sementara pada populasi benih dari UPR terdapat dua ulangan dari tiga ulangan yang terdeteksi positif KHV.

Populasi benih F-1 terseleksi memiliki persentase sintasan lebih tinggi mengindikasikan bahwa populasi tersebut mempunyai daya tahan lebih baik dibandingkan populasi benih F-1 non-seleksi dan benih dari UPR. Hal ini disebabkan populasi benih F-1 terseleksi mempunyai persentase MHC-II lebih tinggi dibandingkan populasi benih F-1 non-seleksi maupun benih dari UPR. Hasil evaluasi secara molekuler menunjukkan bahwa persentase keberadaan MHC-II pada turunan ikan mas F-1 terseleksi sebesar 93,3\%; sedangkan pada benih F-1 non-seleksi hanya 46,6\% yang membawa MHC-II (Hayuningtyas et al., 2012). Hal ini mengindikasikan bahwa populasi F-1 terseleksi sebagian besar memiliki MHC-II dalam tubuhnya yang digunakan sebagai respons imun spesifik terhadap infeksi KHV. MHC-II merupakan sistem pertahanan spesifik yang berperan dalam mengeliminasi parasit dan bakteri, serta menghambat perkembangan virus (Sucipto et al., 2011).

Hasil deteksi gen MHC-II yang dilakukan terhadap ikan uji ditampilkan pada Gambar 3. Pada Gambar 3 menunjukkan bahwa populasi benih F-1 terseleksi semuanya menghasilkan positif MHC-II, sementara pada populasi benih F-1 non-seleksi seluruhnya negatif MHC-II. Pada ikan populasi benih dari UPR hanya ada satu yang terdeteksi memiliki gen MHC-II dalam tubuhnya yaitu pada sampel C3. Dari hasil deteksi keberadaan gen MHC-II tersebut dilakukan analisis lanjut berupa ekspresi MHC-II pada sampel ikan F-1 terseleksi sampel ikan populasi benih F-1 non-seleksi sebagai kontrol negatif.

Fungsi gen MHC-II sebagai respons imun spesifik dibuktikan melalui keberadaan ekspresi gen MHC-II pada beberapa organ yaitu: usus, thymus, ginjal, dan limpa. Gen major histocompatibility complex (MHC) berperan penting dalam pembentukan imunitas terhadap patogen. Beberapa studi menunjukkan ekspresi gen MHC berasosiasi dengan resistensi terhadap

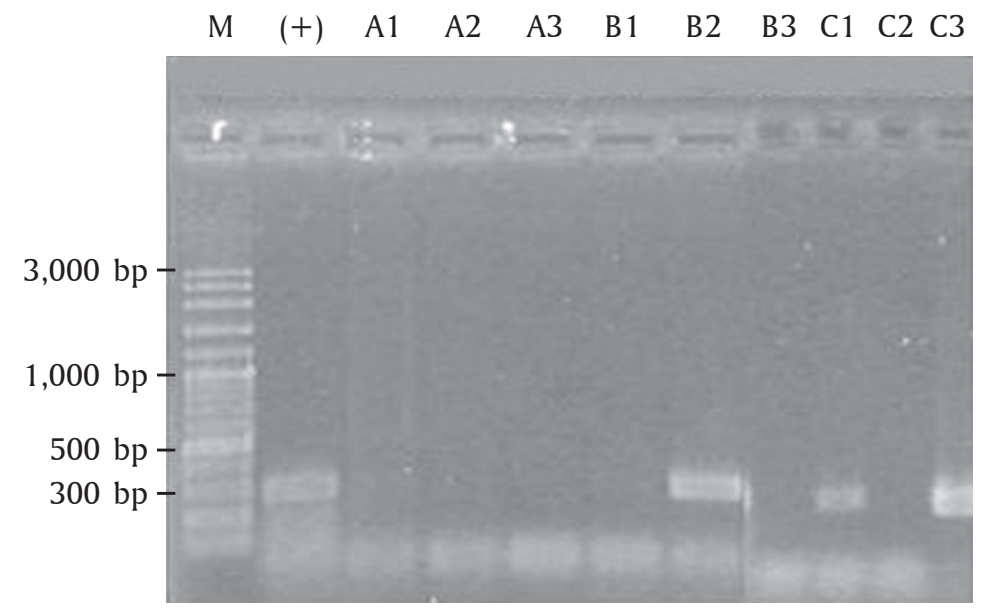

Gambar 2. Hasil deteksi KHV pada ketiga populasi di akhir percobaan. $\mathrm{M}=$ Marker 100 bp DNA leader (vivantis); + = Kontrol positif; A1, A2, A3 = F-1 terseleksi; B1, $\mathrm{B} 2, \mathrm{~B} 3=\mathrm{F}-1$ non-seleksi; $\mathrm{C} 1, \mathrm{C} 2, \mathrm{C} 3=$ Populasi benih dari UPR

Figure 2. The result of $K H V$ detection in third populations in the end of experiment. $M=$ Marker 100 bp DNA leader (vivantis); + = Positive control; A1, A2, A3 = Selected F-1; B1, B2, B3 = Unselected F-1; C1, C2, C3 = Broodstock from Fish Breeding Unit Population 

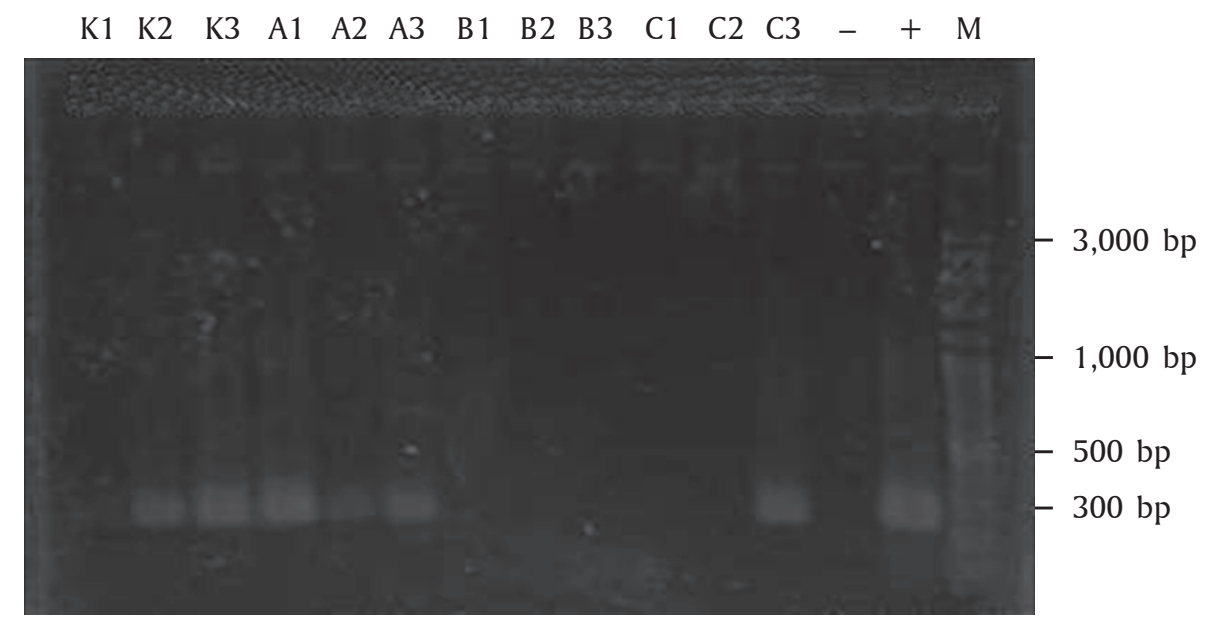

Gambar 3. Hasil deteksi gen MHC-II dari ketiga populasi. $\mathrm{K}=$ Kontrol (+MHC-II); A1, A2, $\mathrm{A} 3$ = F-1 terseleksi; B1, B2, B3 = F-1 non-seleksi; C1, C2, C3 = Populasi benih UPR; $-=$ Kontrol negatif; $+=$ Kontrol positif; $\mathrm{M}=$ Marker

Figure 3. The result of detection gene MHC-II. $K=$ Control (+MHC-II); A1, A2, A3 = Selected F-1; B1, B2, B3 = Unselected F-1; C1, C2, C3 = Broodstock from Fish Breeding Unit Population; $-=$ Negatif control; $+=$ Positive control; $M=$ Marker

patogen pada ikan ciprinid (Rakus et al., 2009; Liu et al., 2013).

Pada Gambar 4A menunjukkan bahwa ekspresi gen MHC-II hanya muncul pada ginjal, limpa, dan thymus. Tetapi dari ketiga organ tersebut, kemunculan ekspresi MHC-II yang dapat dianalisis menggunakan software Gen Analyzer hanya pada ginjal dan limpa. Sementara pada thymus ekspresi yang dihasilkan sangat tipis sehingga sulit dianalisis. Hal ini berbeda dengan penelitian yang dilakukan oleh Rodrigues et al. (1995) menghasilkan ekspresi tertinggi adalah pada organ thymus. Ketidakmunculan ekspresi di thymus diduga akibat jumlah sampel thymus yang diekstrak terlalu sedikit dibanding organ lainnya karena bobot ikan yang digunakan kurang dari $10 \mathrm{~g}$, sementara ikan yang digunakan oleh Rodrigues berkisar 150-250 g.

Gambar 4A juga menunjukkan bahwa pada beberapa sampel ekspresi tertinggi terdapat pada limpa yang ditunjukkan dengan lebih tebalnya fragmen yang dihasilkan dibanding pada ginjal. Berdasarkan data pada Gambar 4A, ekspresi gen MHC-II pada populasi kontrol positif MHC-II dan populasi benih F-1 terseleksi dianalisis sehingga menghasilkan data seperti yang ditampilkan pada Gambar 4B.

Rasio ekspresi gen MHC-II pada ginjal benih F-1 terseleksi lebih rendah dibanding dengan kontrol. Sementara rasio ekspresi gen MHC-II pada limpa benih F-1 terseleksi lebih tinggi dibanding dengan kontrol. Lebih tingginya ekspresi gen MHC-II pada populasi benih F-1 terseleksi di limpa menandakan ekspresinya positif, sedangkan pada ginjal ekspresinya negatif. Menurut Ardeli \& Woo (2006), ginjal meru- pakan organ limfoid utama yang berperan sebagai tempat hidup sel fagositik, sementara thymus dan limpa berfungsi sebagai organ limfoid sekunder. Limfosit di dalam thymus pada ikan setelah dewasa bermigrasi pada limpa. Keberadaan limfosit dapat dilihat melalui preparasi gambaran darah dengan menghitung diferensiasi leukosit.

Hasil analisis gambaran darah benih ikan uji disajikan pada Gambar 5. Berdasarkan Gambar 5 terlihat bahwa secara umum, persentase jumlah limfosit lebih tinggi dibanding sel lainnya.

Menurut Svobodova \& Vykusova (1991), persentase limfosit pada ikan mas berkisar antara 76\%-97,5\% sementara kisaran persentase limfosit yang dihasilkan adalah 47,33\%-91,67\%. Persentase tertinggi limfosit terdapat pada populasi benih F-1 terseleksi sedangkan terendah adalah pada populasi benih F-1 nonseleksi. Menurut Tamba (2006), ikan mas yang sehat memiliki persentase limfosit lebih tinggi dibandingkan ikan yang sakit. Nilai persentase limfosit dihasilkan pada ikan sehat yaitu $54,36 \pm 6,89 \%$ sedangkan pada ikan sakit yaitu $41,9 \pm 15,12 \%$. Hal ini mengindikasikan bahwa populasi benih F-1 terseleksi yang membawa MHC-II dalam keadaan sehat, sementara populasi benih F-1 non-seleksi yang negatif MHC-II dalam keadaan sakit.

Pada populasi benih F-1 non-seleksi juga banyak ditemukan monosit dalam jumlah tinggi sebesar 52,33\%. Monosit akan meningkat jika ada substansi asing pada jaringan atau sirkulasi darah. Populasi benih F-1 non-seleksi dan benih dari UPR merupakan populasi ikan mas yang terserang virus KHV, sementara 
A

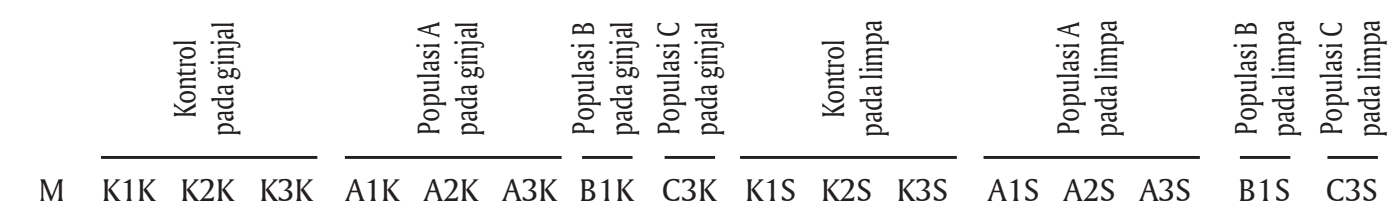

Ekspresi MHC-II

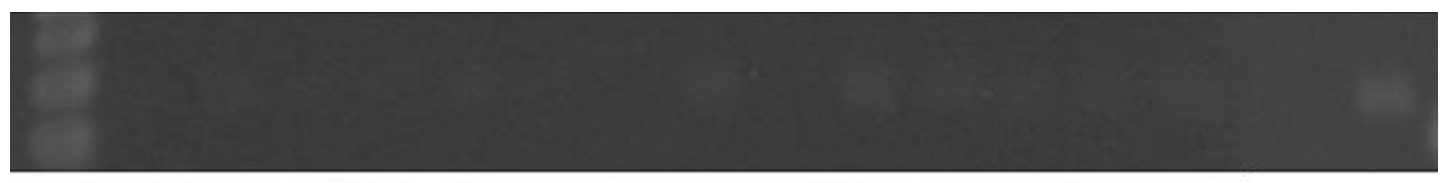

$\beta$-aktin
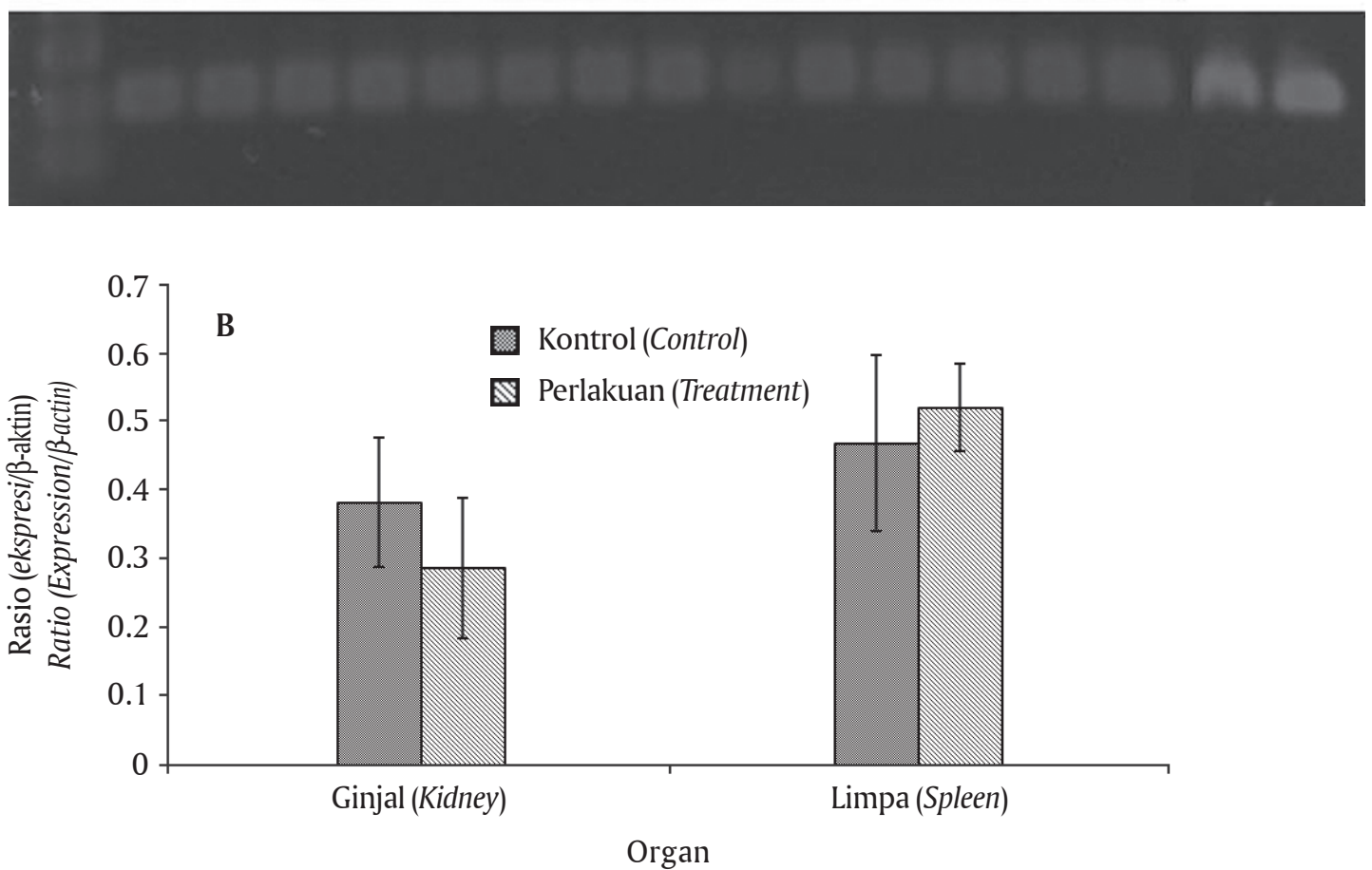

Gambar 4. Analisis semikuantitatif ekspresi gen MHC-II dan $\beta$-aktin pada organ ginjal dan limpa dari benih ikan F-1 terseleksi (M: Marker DNA). Ekspresi gen MHC-II dan $\beta$-aktin pada organ ginjal dan limpa (A). Rasio ekspresi gen MHC-II/ $\beta$-aktin pada benih ikan mas F-1 terseleksi dan kontrol positif MHC-II pada populasi ikan mas (B)

Figure 4. Semi-quantitative analysis of MHC-II gen expression and $\beta$-actin in kidney and spleen organ on F-1 selected broodstock fish (M: DNA Marker). Expression gen MHC-II and $\beta$-actin in kidney and spleen organ (A). Expression ratio of MHC-II gene/ $\beta$-actin on selected F-1 and MHC-II positive control populations of common carp (B)

virus termasuk ke dalam substansi asing yang keberadaannya dapat mengganggu stabilitas sistem di dalam tubuh ikan. Keberadaan jumlah monosit yang tinggi pada populasi tersebut mengindikasikan bahwa di dalam tubuh ikan tersebut terdapat penyakit yang diduga adalah virus KHV.

Persentase keberadaan heterofil cenderung rendah sedangkan eosinofil dan basofil tidak ada di ketiga populasi. Hal ini karena keberadaan heterofil pada ikan mas berkisar 2\%-10\% sedangkan eosinofil akan muncul jika terjadi proses inflamasi akibat infeksi parasit. Ketidakmunculan basofil dikarenakan hanya terdapat pada sebagian kecil spesies ikan dan jumlah kemunculannya lebih sedikit dibanding eosinofil (Vonti, 2008). Ketidakmunculan basofil dan eosinofil juga dapat mengindikasikan bahwa tidak adanya serangan sekunder yang diakibatkan oleh infeksi parasit.

Sebagai data pendukung, dilakukan analisis kualitas air media percobaan. Hasil analisis kualitas air disajikan pada Tabel 1.

Secara umum kualitas air media percobaan sesuai dengan yang dibutuhkan untuk pengujian ketahanan ikan mas terhadap infeksi KHV. Rendahnya suhu air memang diperlukan untuk perkembangan virus KHV sehingga sifat patogennya semakin meningkat, sedangkan parameter fisika-kimia lainnya sesuai dengan batas toleransi ikan mas. Hal ini mendukung hasil percobaan yang menunjukkan bahwa kematian ikan pada saat uji tantang disebabkan oleh faktor perlakuan dan tidak oleh faktor lingkungan media pemeliharaan. 


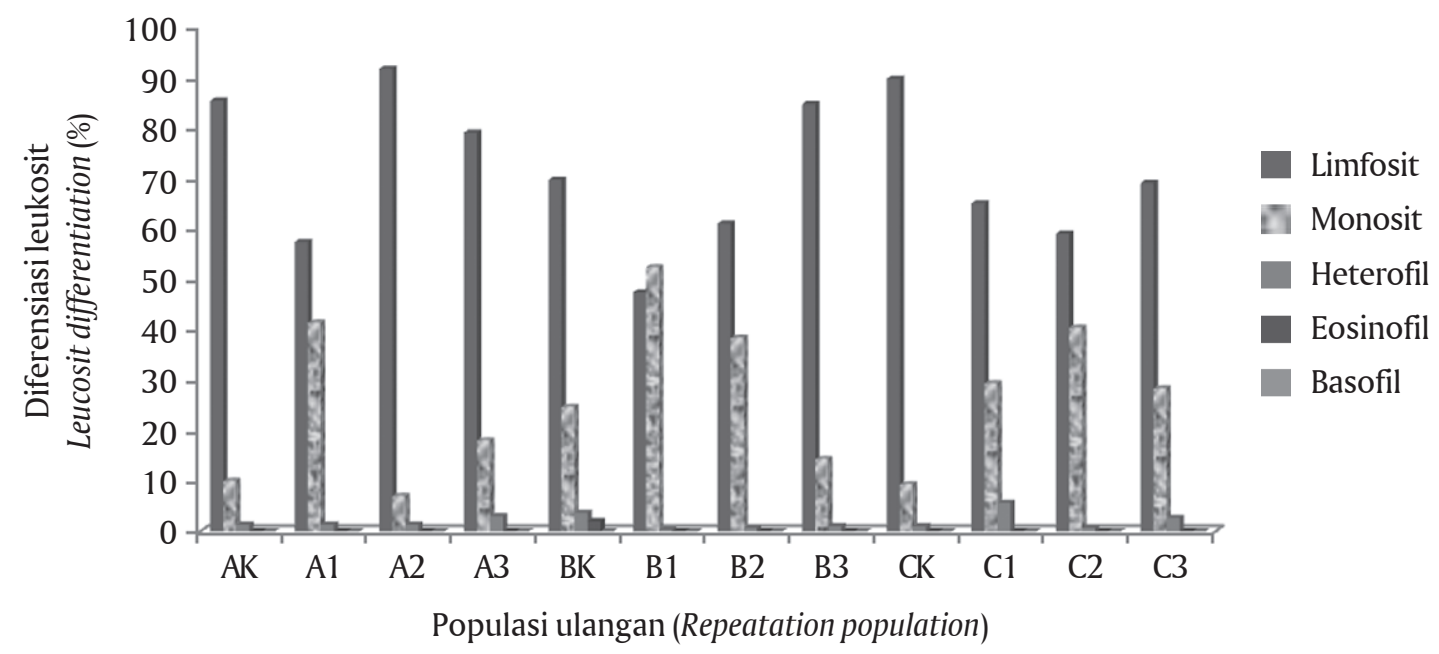

Gambar 5. Persentase diferensiasi leukosit pada ikan uji. A = F-1 terseleksi; B = F-1 nonseleksi; $\mathrm{C}=$ Benih dari UPR; $\mathrm{K}=$ Perlakuan kontrol; and 1, 2, $3=$ Ulangan

Figure 5. Differentiation leucosit percentage on fish test. $A=F-1$ selected; $B=$ Non-selected F-1, $C=$ Fish from backyard hatchery; $K=$ Control population; and 1, 2, $3=$ Repeatation

Tabel 1. Data kualitas air pada saat uji tantang ikan mas dengan KHV

Table 1. Water quality in the common carp challenge test to KHV

\begin{tabular}{lc}
\multicolumn{1}{c}{$\begin{array}{c}\text { Parameter } \\
\text { Parameters }\end{array}$} & $\begin{array}{c}\text { Kisaran minimal-maksimal } \\
\text { Minimal-maximal values }\end{array}$ \\
\hline Suhu (Temperature $)\left({ }^{\circ} \mathrm{C}\right)$ & $19.2-24$ \\
$\mathrm{pH}$ & $6.63-8.06$ \\
Oksigen terlarut $($ Dissolved oxygen $)(\mathrm{mg} / \mathrm{L})$ & $3.99-8.36$ \\
TAN $(\mathrm{mg} / \mathrm{L})$ & $0.0028-1.2865$ \\
Nitrit $($ Nitrite $)(\mathrm{mg} / \mathrm{L})$ & $0.0068-2.9400$ \\
Nitrat $($ Nitrate $)(\mathrm{mg} / \mathrm{L})$ & $0.0000-13.0189$ \\
Konduktivitas $($ Conductivity $)(\mathrm{mg} / \mathrm{L})$ & $0.12-1.44$ \\
Kekeruhan $($ Turbidity $)$ & $10-67$ \\
\hline
\end{tabular}

\section{KESIMPULAN}

Populasi benih F-1 terseleksi memiliki daya tahan lebih baik dengan sintasan sebesar 93,33\%; dibandingkan populasi F-1 non-seleksi dan benih dari UPR masing-masing sebesar $85,55 \%$ dan $81,11 \%$. Hal ini didukung tingginya persentase jumlah limfosit, serta rendahnya persentase monosit dan heterofil pada populasi benih F-1 terseleksi dibanding populasi lainnya. Ekspresi MHC-II tertinggi pada benih ikan mas terdapat pada organ limpa.

\section{UCAPAN TERIMA KASIH}

Terima kasih disampaikan kepada Sdr. Lamanto, S.Pi., staf peneliti BPPI dan semua teknisi yang terlibat dalam kegiatan ini, Sdr. Nurfansuri, A.Md.; Listiyo Dharmawanto; Supriyanto A.Md.; dan Nikmatullah. Penelitian ini dibiayai oleh APBN melalui DIPA 2012 pada Balai Penelitian Pemuliaan Ikan (BPPI), Sukamandi.

\section{DAFTAR ACUAN}

Anonim. (2010). Protokol pemuliaan ikan mas. Pusat pengembangan induk ikan mas nasional. Direktorat Jenderal Perikanan Budidaya. Kementerian Kelautan dan Perikanan. Jakarta, $39 \mathrm{hlm}$.

Ardelli, B.F., \& Woo, P.T.K. (2006). Immunocompetent cells and their mediators in fin fish. In Woo, P.T.K., \& Bruno, D.W. (Eds.), UK: CABI Publishing. Fish Disease and Disorders, 3(2), 702-724.

Ariyanto, D., Hayuningtyas, E.P., \& Syahputra, K. (2010a). Koleksi dan karakterisasi populasi ikan mas sebagai bahan pembentuk ikan mas tahan KHV. Seminar Hasil Penelitian LRPTBPAT tahun 2010. Sukamandi, 13-14 Desember 2010.

Ariyanto, D., Hayuningtyas, E.P., \& Syahputra, K. (2010b). Evaluasi daya tahan lima strain ikan mas terhadap KHV. Seminar Hasil Penelitian LRPTBPAT tahun 2010. Sukamandi, 13-14 Desember 2010. 
Hayuningtyas, E.P., Ariyanto, D., Syahputra, K., \& Lamanto. (2012). Evaluasi performansi benih F-1 ikan mas tahan KHV dari populasi induk F-0 terseleksi. Laporan Teknis Akhir Kegiatan 2012, 19 hlm.

Hayuningtyas, E.P., Ariyanto, D., \& Syahputra, K. (2013). Hubungan antara pertumbuhan dengan keberadaan gen tahan penyakit Major Histocompatibility Complex (MHC) pada ikan mas (Cyprinus carpio).J. Ris. Akuakultur, 8(3), 383-391.

Liu, J., Liu, Z.Z., Zhao, J.X., \& Wang, C.H. (2013). MHC class II $\alpha$ alleles associated with resistance to Aeromonas hydrophila in purse red common carp, Cyprinus carpio Linnaeus. Short Communication. Journal of Fish Diseases. http://onlinelibrary.wiley. com/doi/10.1111/jfd.12131/abstract diakses 5 Mei 2014.

Mudjiutami, E., Ciptoroso, Zainun, Z., Sumarjo, \& Rahmat. (2007). Pemanfaatan immunostimulan untuk pengendalian penyakit pada ikan mas. Jurnal Budidaya Air Tawar, 4(1), 1-9.

Rakus, K.L., Wiegertjes, G.F., Adamek, M., Bekh, V., Stet, R.J.M., \& Irnazarow, I. (2008). Application of PCR-RF-SSCP to study major histocompatibility class II B polymorphism in common carp (Cyprinus carpio L.). Fish \& Shellfish Immunology, 24, 734-744.

Rakus, K.L., Wiegertjes, G.F., Jurecka, P., Walker, P.D., Pilarczyk, A., \& Irnazarow, I. (2009). Major histocompatibility (MH) class II $B$ gene polymorpishm influences disease resistance of common carp (Cyprinus carpio L.). Aquaculture, 288, 44-50.

Rodrigues, P.N.S., Hermsen, T.T., Rombout, J.H.W.M., Egberts, E., \& Stet, R.J.M. (1995). Detection of
MHC class II transcripts in lymphoid tissuies of the common carp (Cyprinus carpio L.). Developmental and Comparative Immunology, 19(6), 483-496.

Santika, A., Ciptoroso, Zainun, Z., Sumarjo, \& Suroso. (2008). Vaksinasi ikan mas untuk meningkatkan daya tahan tubuh terhadap infeksi koi herpes virus (KHV). Abstraksi $1 \mathrm{hlm}$.

Sunarto, A. (2005). Epidemologi penyakit koi herpes virus (KHV) di Indonesia. Dalam: Supriyadi, H., \& Priono, B. (Eds.). Strategi pengelolaan dan pengendalian penyakit KHV. Pusat Riset Perikanan Budidaya. Jakarta, hlm 31-40.

Sucipto, A., Yanti, D.H., Djajanurdjasa, A., \& Muharam, C. (2011). Produksi calon induk ikan mas tahan penyakit. Jurnal Budidaya Air Tawar, hlm. 12-19.

Svobodová, Z., \& Vykusová, B. (1991). Haematological examination of fish. In: Svobodová, Z., \& Vykusová, B. (Eds.). Manual for International Training Course on Fresh-Water Fish Diseases and Intoxications: Diagnostics, Prophylaxis and Therapy. Czechoslovakia. Research Institute of Fish Culture and Hydrobiology Vodnany, 55 pp.

Tamba, A. (2006). Kerentanan dan gambaran darah ikan mas (Cyprinus carpio L) yang terinfeksi Koi Herpes Virus (KHV). Disertasi. Pascasarjana IPB. Bogor, 93 hlm.

Vonti, O. (2008). Gambaran darah ikan mas (Cyprinus carpio Linn.) strain sinyonya yang berasal dari daerah Ciampea-Bogor. Skripsi. Fakultas Kedokteran Hewan. IPB. Bogor, $60 \mathrm{hlm}$.

Zainun, Z. (2007). Pengamatan parameter hematologis pada ikan mas yang diberi immunostimulan. Buletin Teknik Litkasaya Akuakultur, 6(1), 45-49. 